\title{
Growth and slaughtering performance of three rabbit genotypes under different environmental conditions
}

\author{
GM Chiericato, C Rizzi, V Rostellato \\ Dipartimento di Scienze Zootecniche, Università di Padova, Via Gradenigo, 6, 35131 Padova, Italy
}

(Received 22 March 1995 ; accepted 11 December 1995)

\begin{abstract}
Summary - This experiment studied the influence of different genotypes and different seasons on rabbit meat production performance. The genotypes New Zealand White (NZW), Hyla $(H)$ and Provisal $(P)$ were compared. The trials were carried out in summer $(\mathrm{S})\left(26^{\circ} \mathrm{C}\right)$ and in winter $(\mathrm{W})\left(11^{\circ} \mathrm{C}\right)$. The genotype did not affect the productive performance. Daily weight gain, intake and feed efficiency decreased during $S(P<0.01)$. NZW displayed $(P<0.01)$ a lower hind feet proportion and a higher liver percentage with respect to the crossbreds. NZW differed $(P<0.01)$ from $P$ for empty stomach and gut, whereas the values for $\mathrm{H}$ were intermediate. There was a higher proportion of forelegs $(P<0.05)$ and $(P<0.01)$ heart, kidneys, empty stomach and gut and a lower proportion $(P<0.01)$ of hot carcass during $W$. Purebreds had a higher percentage (hot carcass weight) of head $(P<0.05)$ and lower percentages of shoulders, forelegs $(P<0.05)$, rump, nates and thighs $(P<0.01)$ in comparison with $\mathrm{H} ; \mathrm{P}$ showed intermediate values. $W$ induced a higher $(P<0.01)$ proportion (hot carcass weight) of head, shoulders and forelegs and fat.
\end{abstract}

rabbit / genotype / season / meat production

Résumé - Performances d'élevage et d'abattage de trois types génétiques de lapins soumis à des conditions environnementales différentes. Le but de l'expérimentation était d'étudier l'influence du génotype et de la saison sur les performances d'élevage et d'abattage du lapin. Au total, 43 lapins Blancs de Nouvelle Zélande (NZW), 43 Hyla (H) et 44 Provisal (P), âgés de 43 jours et de sexe féminin, ont été élevés jusqu'à l'âge de 85 jours. La première expérimentation a été réalisée en été (S) à une température moyenne de $26^{\circ} \mathrm{C}$ et à une humidité relative de $73 \%$. La deuxième expérimentation a été effectuée en hiver $(W)$ à une température de $11^{\circ} \mathrm{C}$ et à une humidité relative de $65 \%$. L'alimentation en pellet était fournie ad libitum. $\dot{A}$ la fin des essais, 20 lapins de chaque génotype et de chaque saison ont été abattus. L'absence d'interaction significative entre le génotype et la saison montre que les génotypes testés ont la même capacité d'adaptation à des conditions de températures différentes. La croissance $(33,0$ g/jour), l'ingestion alimentaire $(123,2 \mathrm{~g} / j \mathrm{our})$ et l'indice de consommation $(3,73 \mathrm{~g} / \mathrm{g})$ ont été semblables pour les trois groupes. La saison $S$ a notablement réduit $(\mathrm{p}<0,01)$ l'accroissement pondéral (29,1 vs 37,2 g/jour), la consommation $(94,4 \mathrm{vs} 153,6 \mathrm{~g} / j \mathrm{our})$ et l'indice de consommation $(3,24$ vs $4,13 \mathrm{~g} / \mathrm{g})$. Les données d'abattage, rapportées au poids vif vide, montrent 
que le poids des manchons arrière est plus faible $(p<0,01)$ chez les $N Z W$, tandis que celui du foie est plus élevé $(p<0,01)$. Comparativement aux $P$, les NZW ont présenté un poids d'estomac et d'intestins vides inférieur $(\mathrm{p}<0,01)$, les $H$ étant intermédiaires. Avec la saison $W$, les poids des pattes avant $(\mathrm{p}<0,05)$, du cour $(\mathrm{p}<0,01)$, des reins $(\mathrm{p}<0,01)$, de l'estomac et des intestins vides $(\mathrm{p}<0,01)$ sont plus élevés. En revanche, le poids de la carcasse chaude est plus faible $(\mathrm{p}<0,01)$. Les données de dissection, exprimées en pourcentage du poids de la carcasse chaude, mettent en évidence que le poids de la tête et du cou $(p<0,05)$ est plus élevé chez les $N Z W$ que chez les $H$, les poids des épaules et des pattes avant $(\mathrm{p}<0,05)$, du rable $(\mathrm{p}<0,01)$ étant plus faibles. La saison $W$ a augmenté les poids de la tête et du cou, des épaules et des pattes avant, ainsi que l'ensemble des dépôts adipeux. Les sujets $N Z W$ ne diffèrent pas des hybrides en termes de performance de croissance, mais seulement en termes d'abattage et de dissection. Par rapport à la saison $S$, la $W$ a amélioré l'efficacité alimentaire et les performances zootechniques des lapins.

lapin / génotype / saison / production de viande

\section{INTRODUCTION}

In recent years, the genotype has become one of the most important factors in rabbit breeding. Although purebreds (New Zealand White and Californian) have been progressively replaced by hybrid commercial-type rabbits, few experiments have been undertaken to compare the performance of these hybrid commercial-type rabbits with those of purebreds (Okerman et al, 1987; Chiericato and Filotto, 1989; Ristic and Zimmermann, 1992).

Another factor that plays a primary role in the rabbit productive cycle is the environmental temperature, in particular for countries characterized by extreme temperatures of cold in winter and hot in summer. Although the rabbit susceptibility to temperature stress is well known, only a limited amount of experimental work has been conducted testing these animals' reactions to different thermic conditions in terms of meat production performance (Stephan, 1981; Simplicio et al, 1988; Chiericato et al, 1992).

The aim of this study was to investigate the productive and slaughtering performance of three rabbit genotypes under different environmental conditions to better understand their effects on the meat production of female rabbits.

\section{MATERIALS AND METHODS}

The experiment was conducted during the winter (W) and summer (S) of 1992 to compare the effects of these two environmental conditions.

\section{Animals and diet}

The trial was carried out on 43,43 and 44, 43day-old female rabbits, belonging to New Zealand White (NZW), Hyla $(\mathrm{H})$ and Provisal $(\mathrm{P})$ genotypes, respectively. $\mathrm{H}$ and $\mathrm{P}$ genotypes were commercial-type rabbits obtained from crossing two therminal synthetic lines. The purebreds originated from a firm registered with the Italian Breeders Association; the hybrids came from farms recommended by the firms that had produced the grandparents. The females of each genotype were produced from the same sires and dams for the two season groups. The females were taken from no less than ten litters obtained from ten sires; the rearing conditions and the breeding farm characteristics were all similar.

The rabbits were maintained until the age of 85 days, and were given ad libitum access to water and commercial pellets composed of dehydrated lucerne meal ( $36.30 \%)$, barley meal $(19 \%)$, wheat middlings (16\%) and soybean meal $(8 \%)$. The feed was analyzed chemically (AOAC, 1984; Martillotti et al, 1987), and the concentration of digestible energy was estimated according to the Parigi Bini and Dalle Rive (1977) equation. 


\section{Housing conditions and environmental monitoring}

The animals were housed in an individual industrial-type cage system $\left(1120 \mathrm{~cm}^{2} / \mathrm{female}\right)$, that did not prevent caecotrophy.

Inside the rearing rooms, air diffusion was obtained by forced ventilation of outside air; there were no air heating or cooling systems. The photoperiod consisted of $16 \mathrm{~h}$ of light and $8 \mathrm{~h}$ of dark, provided by fluorescent lamps; the mean light intensity was $32 \pm 4$ lux. The environmental temperature and the relative humidity values were continuously recorded by a thermoigrograph (TIG - 1TH LSI), and the light intensity was monitored every 5 days by a luxmeter HD 8366 (Delta $\mathrm{Ohm})$. The ammonia concentration inside the rooms was checked every 7 days by a Dräger pump and kits and the mean values ranged from 4 to $7 \mathrm{ppm}$.

\section{Experimental procedures}

The feed intake and health status of each rabbit were examined daily; the live weight and body gain measurements were conducted on a weekly basis. At the end of the experiment, 20 animals of each genotype were slaughtered and jointed for both seasonal trials.

The slaughtered animals were bled initially by severing the carotid arteries and jugular veins. They were then skinned. The weight of the pelt (whole skin), the head and neck, separated by cutting through the seventh cervical vertebra and the first thoracic vertebra, and the weight of distal fore- and hindlegs with pelt, removed by dissection through the antebrachio-carpal and tibiotarsal joints, were recorded. The weights of the stomach and gut (full and empty), heart, liver and kidneys, and perirenal, perivisceral and scapular fat were recorded. The head and neck were then cut, without pelt, separated as just described. The shoulders and forelegs were separated from the trunk by sectioning, around the shoulders, the caudal border of the triceps brachii muscle and cutting the pectoral and the trapezius and rhomboideus muscles. Two other cross sections, one cranial along the caudal edge of the last rib and the other caudal, following a vertical line on the tuber coxal, were used to separate the three joints of thoracic cage, loins and flanks and rump, nates and thighs.

\section{Statistical analysis}

The data obtained, after examining the variance homogeneity, were submitted to statistical analysis using the model I and the Harvey (1989) package, according to the following model:

$$
Y_{\mathrm{ijk}}=\mu+G_{\mathrm{i}}+T_{\mathrm{j}}+\left(G T_{\mathrm{ij}}+e_{\mathrm{ijk}}\right.
$$

where: $Y_{i j k}=$ experimental data; $\mu=$ overall mean; $G_{i}=$ fixed effect of $i$-th genotype $(i=1,2,3)$; $T_{\mathrm{j}}=$ fixed effect of $j$-th season $(j=1,2) ;\left(G T_{\mathrm{ij}}=\right.$ interaction effect; $e_{\mathrm{ijk}}=$ residual random effect .

The data concerning the zootechnical performance and the fat deposit weights were submitted to covariance analysis for initial body weight and hot carcass weight, respectively.

\section{RESULTS AND DISCUSSION}

\section{Environmental conditions and diet employed}

Table I shows the temperature and the relative humidity values observed during the two seasons. In summer, the highest temperatures were observed in the middle of the day, between 0900 and 2400 hours, with a mean value of $27.2 \pm 2.56{ }^{\circ} \mathrm{C}$. These temperature levels were high and some authors (Grazzani and Dubini, 1982; Samoggia, 1987) report that the production performance is affected above $25^{\circ} \mathrm{C}$. The limited thermic differences observed between night and day, equivalent to $2.6^{\circ} \mathrm{C}$, did not seem to exert the positive effect recorded by Maertens and De Groote (1990).

The relative humidity reached mean values of $80 \%$ during the night and $70 \%$ at the hottest time of the day. These levels did not seem to have any negative effects on the animals. 
Table I. Mean \pm SD of temperature and relative humidity observed during the two different seasons.

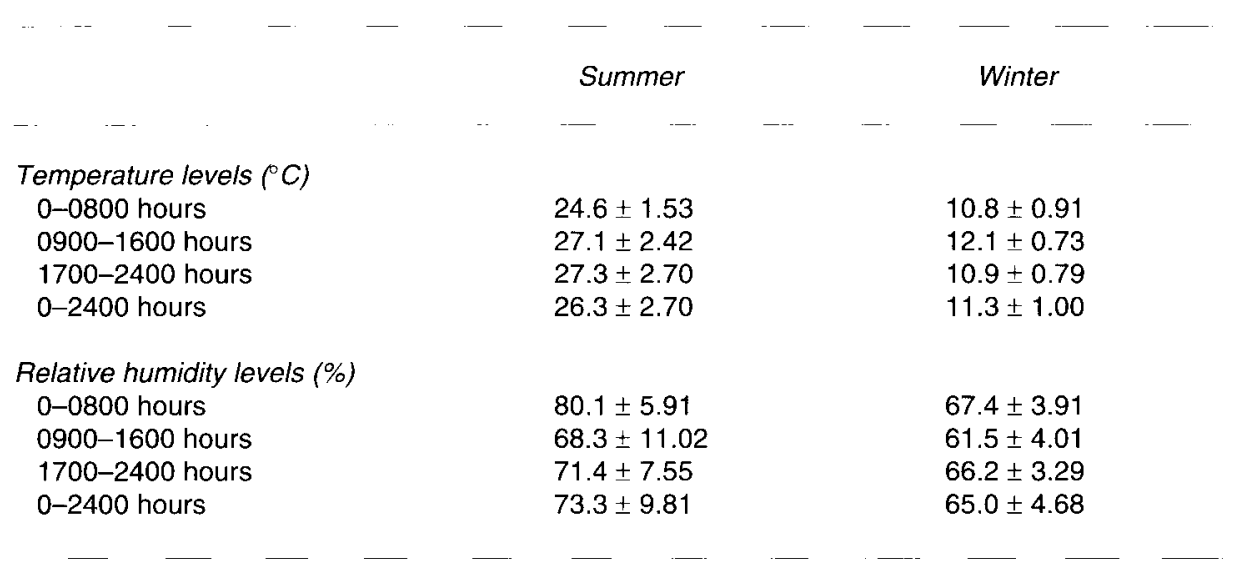

In the second part of the experiment, during the winter season, mean thermic levels were relatively low and constant and equivalent to $11.3 \pm 1.0^{\circ} \mathrm{C}$, with limited differences between day and night. The thermic conditions of this trial were below the area of thermal neutrality and therefore capable of stressing the female rabbits.

The literature indicates that a range from 15 to $20^{\circ} \mathrm{C}$ is the most ideal for the meat production phase (Roca Casanovas et al, 1980). The relative humidity values ranged from 58 to $71 \%$, which are considered suitable for meat production (Roca Casanovas et al, 1980).

The chemical composition and nutritive value of the feed are shown in table II. The feed had a commercial-type formulation and was suitable for rabbit meat production (Cheeke, 1987; INRA, 1989).

\section{Productive performance}

Because no significant interactive effects were found between the genotypes and the climatic conditions, the tables present only the main effect of the treatments. This result pointed out that the genetic types tested had similar adaptive capacities to the dif-
Table II. Chemical composition and nutritive value of the diet (means $\pm \mathrm{SD}$ ).

\begin{tabular}{|c|c|c|}
\hline Dry matter (DM) & $\%$ & 89.50 \\
\hline Crude protein $(\mathrm{N} \times 6.25)$ & 5) $\% \mathrm{DM}$ & $18.90 \pm 0.25$ \\
\hline Ether extract & $\% \mathrm{DM}$ & $4.30 \pm 0.31$ \\
\hline Ash & $\% \mathrm{DM}$ & $7.90 \pm 0.33$ \\
\hline $\mathrm{N}$-free extract & $\%$ DM 5 & $52.80 \pm 1.10$ \\
\hline Crude fiber & $\% \mathrm{DM}$ & $16.10 \pm 0.41$ \\
\hline NDF & $\%$ DM 2 & $29.56 \pm 1.95$ \\
\hline ADF & $\%$ DM & $19.27 \pm 0.97$ \\
\hline Calcium & $\%$ DM & $1.15 \pm 0.17$ \\
\hline Phosphorus & $\% \mathrm{DM}$ & $0.74 \pm 0.13$ \\
\hline Magnesium & $\%$ DM & $0.28 \pm 0.04$ \\
\hline Potassium & $\% \mathrm{DM}$ & $1.54 \pm 0.09$ \\
\hline Digestible energy & $\mathrm{kcal} / \mathrm{kg} \mathrm{DM}$ & 2858 \\
\hline & $\mathrm{MJ} / \mathrm{kg} \mathrm{DM}$ & 11.96 \\
\hline
\end{tabular}

ferent environmental conditions. Table III shows that, for animals of the same age, NZW rabbits presented an initial live weight of $1076 \mathrm{~g}$. This was $12.7 \%$ lower than that of hybrids who weighed, on average, 1232 $\mathrm{g}$. This weight difference in rabbits of the same age was due to the performance of the mothers and pups at weaning.

The other productive performances demonstrated covariance for initial body weight: the two hybrid genotypes showed a mean weight gain of $33.1 \mathrm{~g} /$ day, similar 
Table III. Zootechnical performance according to genotype and environmental condition.

\begin{tabular}{|c|c|c|c|c|c|c|}
\hline \multirow{3}{*}{$\cdots \cdots$} & \multicolumn{3}{|c|}{ - } & \multicolumn{2}{|c|}{$-\ldots$} & \multirow{2}{*}{ Error mean } \\
\hline & \multicolumn{3}{|c|}{ Genotypes } & \multicolumn{2}{|c|}{ Seasons } & \\
\hline & $N Z W$ & $H$ & $P$ & $S$ & $w$ & square \\
\hline Animals (no) & 43 & 43 & 44 & 65 & 65 & \\
\hline Initial body weight $(\mathrm{g})$ & $1076^{\mathrm{Bb}}$ & $1236^{\mathrm{Aa}}$ & $1228 \mathrm{Aa}$ & $1243^{A}$ & $1117^{8}$ & $8608^{2}$ \\
\hline Final body weight $(\mathrm{g})^{1}$ & $2473^{B b}$ & $2623^{\mathrm{Aa}}$ & $2617 \mathrm{Aa}$ & $2432^{B}$ & $2710^{A}$ & 292943 \\
\hline Body weight gain (g/day) ${ }^{1}$ & 32.9 & 33.0 & 33.1 & $29.1^{B}$ & $37.2^{\mathrm{A}}$ & 23.943 \\
\hline Feed intake $(\mathrm{g} / \text { day })^{1}$ & 126.5 & 122.1 & 121.0 & $94.4^{\mathrm{B}}$ & $153.6^{\mathrm{A}}$ & $130.40^{3}$ \\
\hline Feed efficiency $(\mathrm{g} / \mathrm{g})^{1}$ & 3.85 & 3.70 & 3.65 & $3.24 \mathrm{~B}$ & $4.13^{A}$ & $0.1508^{3}$ \\
\hline
\end{tabular}

ab Values with different superscripts within the same raw differ by $P<0.05 ; A B$ values with different superscripts within the same row differ by $P<0.01 ;{ }^{1}$ values covariated for initial body weight; ${ }^{2} 124$ degrees of freedom; ${ }^{3} 123$ degrees of freedom; NZW: New Zealand White; H: Hyla; P: Provisal; S: summer; W: winter.

to that of purebred rabbits $(32.9 \mathrm{~g} /$ day $)$. A very limited number of experiments have been conducted to compare the performances of the genotypes considered in this trial. Other research undertaken in Belgium (Belgium Government Agricultural Research Center, 1984) and Italy (Chiericato and Filotto, 1989) confirm these results.

Because feed intake was also similar among the groups, the resultant feed efficiency did not significantly differ, and had a mean value of $3.73 \mathrm{~g} / \mathrm{g}$. These results are in agreement with data from previous experiments (Belgium Government Agricultural Research Center, 1984; Okerman et al, 1987; Chiericato and Filotto, 1989). The W animals had an initial body weight that was significantly lower $(P<0.01)$ than those of the $S$ group (1117 vs $1243 \mathrm{~g}$ ). The seasonal temperature levels influenced the daily weight gain, which resulted in a higher daily gain in $W$ than in $S$ rabbits (37.2 vs $29.1 \mathrm{~g}$, $P<0.01)$. This increment was due to a higher feed intake observed during the $W$ experiment (153.6 vs $94.4 \mathrm{~g}$ /day, $P<0.01$ ).

Given the temperature stress effect on growth and feed intake, the feed efficiency was less favorable $(P<0.01)$ during $W$ than during $S$ ( 4.13 vs $3.24 \mathrm{~g} / \mathrm{g}$ ). These findings agree with those obtained in our previous trial (Chiericato et al, 1992) and with those reported by others (Stephan, 1981; Lebas and Ouhayoun, 1987; Simplicio et al, 1988).

No particular diseases affected the animals throughout the rearing period of the two trials. The mortality rate values were similar among the experimental groups, and averaged $3.8 \%$.

\section{Slaughtering and jointing performance}

The slaughtering performance of the animals is presented in table IV. The pelt and the head and neck percentages of empty body weight were similar among the genotypes with a mean value of 15.40 and $10.57 \%$, respectively. For the distal legs, it was observed that only the hindleg proportion was different among the genotypes, being higher $(P<0.01)$ in the $\mathrm{H}$ and $\mathrm{P}$ rabbits $(2.34$ and $2.40 \%$ ) with respect to NZW animals $(2.20 \%)$. The three tested genotypes presented similar values for the distal forelegs $(0.82 \%)$, heart $(0.42 \%)$ and kidneys $(0.69 \%)$. The NZW rabbits displayed a higher proportion $(P<0.01)$ of liver $(4.62 \%)$ than $\mathrm{H}(3.58 \%)$ and $\mathrm{P}(3.91 \%)$ rabbits. The 
Table IV. Slaughtering performance according to genotype and environmental condition.

\begin{tabular}{|c|c|c|c|c|c|c|}
\hline & \multirow{2}{*}{ NZW } & \multirow{2}{*}{$\frac{\text { Genotypes }}{H}$} & \multirow[b]{2}{*}{$P$} & \multicolumn{2}{|c|}{ Seasons } & Error mean \\
\hline & & & & $S$ & $w$ & square \\
\hline Animals (no) & 40 & 40 & 40 & 60 & 60 & \\
\hline Preslaughter weight (g) & $2534^{B b}$ & $2626^{\mathrm{AaB}}$ & $2723^{A a}$ & $2491^{B}$ & $2765^{A}$ & 279233 \\
\hline Empty body weight $(\mathrm{g})$ & $2216^{B c}$ & $2292^{A B b}$ & $2370^{A a}$ & $2193^{B}$ & $2393^{A}$ & $25256^{3}$ \\
\hline \multicolumn{7}{|l|}{$\%$ of empty body weight } \\
\hline Pelt & 15.55 & 15.29 & 15.35 & 15.00 & 15.80 & $0.6393^{3}$ \\
\hline Head and neck 1 & 10.69 & 10.55 & 10.47 & 10.89 & 10.25 & $0.3274^{3}$ \\
\hline Distal forelegs & 0.79 & 0.84 & 0.83 & $0.79^{b}$ & $0.84^{a}$ & $0.0051^{3}$ \\
\hline Distal hindlegs & $2.20^{\mathrm{Bb}}$ & $2.34^{\mathrm{Aa}}$ & $2.40^{\mathrm{Aa}}$ & 2.31 & 2.32 & $0.0203^{3}$ \\
\hline Heart & 0.41 & 0.43 & 0.41 & $0.36^{\mathrm{B}}$ & $0.46^{\mathrm{A}}$ & $0.0015^{3}$ \\
\hline Liver & $4.62^{\mathrm{Aa}}$ & $3.58^{\mathrm{Bc}}$ & $3.91^{\mathrm{Bb}}$ & 4.02 & 4.05 & $0.3345^{3}$ \\
\hline Kidneys & 0.70 & 0.67 & 0.69 & $0.59^{\mathrm{B}}$ & $0.79^{A}$ & $0.0038^{3}$ \\
\hline Empty stomach and gut & $5.21^{B c}$ & $5.32^{A b}$ & $5.42^{\mathrm{Aa}}$ & $5.15^{\mathrm{B}}$ & $5.49^{A}$ & $0.0300^{3}$ \\
\hline Hot carcass ${ }^{2}$ & 64.85 & 65.70 & 65.60 & $65.91^{A}$ & $64.86^{\mathrm{B}}$ & $1.8772^{3}$ \\
\hline
\end{tabular}

ab Values with different superscripts within the same raw differ by $P<0.05 ; A B$ values with different superscripts within the same row differ by $P<0.01 ;{ }^{1}$ values covariated for initial body weight; ${ }^{2} 124$ degrees of freedom; ${ }^{3} 123$ degrees of freedom; NZW: New Zealand White; H: Hyla; P: Provisal; S: summer; W: winter.

proportion of empty stomach and gut seemed to be lower $(P<0.01)$ in purebred rabbits $(5.21 \%)$ with respect to those of $P$ genotype $(5.42 \%)$. The $\mathrm{H}$ data were intermediate with a value of $5.32 \%$. The hot carcass percentage did not differ among the three breed groups, averaging $65.38 \%$. These overall results from the three tested genotypes confirm the data reported by other studies (Okerman et al, 1987; Chiericato and Filotto, 1989).

The female rabbits presented a higher hot carcass percentage $(P<0.01)$ in $S$ than in W (65.91 vs $64.86 \%$, table IV). This result was due to a higher proportion of the distal forelegs $(0.84$ vs $0.79 \%, P<0.05)$, heart (0.46 vs $0.36 \%, P<0.01$ ), kidneys ( 0.79 vs $0.59 \%, P<0.01)$ and empty stomach and gut (5.49 vs $5.15 \%, P<0.01$ ) recorded in $W$ rabbits. The lower values for stomach and gut can probably be attributed to the lower $S$ feed intake. These results confirm those obtained in a previous study (Chiericato et al, 1992).

The jointing data are summarized in table $V$. The NZW rabbits were significantly different from $\mathrm{H}$ subjects for head and neck (13.58 vs $12.82 \%, P<0.05)$ and shoulders and forelegs (11.60 vs $11.93 \%, P<0.05$ ); the $P$ rabbits were intermediate (13.14 and $11.78 \%$ ).

The commercial joint preparations showed no significant differences between genotype with regard to thoracic wall and loins and flanks that averaged, for the three genotypes, 23.54 and $17.51 \%$, respectively. These results are in agreement with those reported in our previous experiment (Chiericato and Filotto, 1989).

The $\mathrm{H}$ hybrids presented a higher $(P<$ $0.01)$ proportion of rump, nates and thighs with respect to the purebred rabbits (34.58 vs $33.36 \%$ ), whereas $P$ showed an intermediate value $(34.06 \%)$. A similar result 
Table V. Carcass jointing performance according to genotype and environmental condition.

\begin{tabular}{|c|c|c|c|c|c|c|}
\hline & \multicolumn{3}{|c|}{ Genotypes } & \multicolumn{2}{|c|}{ Seasons } & \multirow{2}{*}{$\begin{array}{c}\text { Error mear } \\
\text { square }\end{array}$} \\
\hline & $N Z W$ & $H$ & $P$ & $S$ & $W$ & \\
\hline Animals (no) & 30 & 30 & 30 & 45 & 45 & \\
\hline \multicolumn{7}{|l|}{$\%$ hot carcass weight } \\
\hline Head and neck 1 & $13.58^{a}$ & $12.82^{b}$ & $13.14^{\mathrm{ab}}$ & $12.84^{\mathrm{B}}$ & $13.52^{\mathrm{A}}$ & $0.7143^{3}$ \\
\hline Shoulders and forelegs & $11.60^{\mathrm{b}}$ & $11.93^{a}$ & $11.78^{a b}$ & $11.29^{B}$ & $12.25^{A}$ & $0.1755^{3}$ \\
\hline Thoracic cage & 24.08 & 23.12 & 23.42 & 23.69 & 23.37 & $1.4955^{3}$ \\
\hline Loins and flanks & 17.38 & 17.55 & 17.60 & 17.73 & 17.29 & $1.4238^{3}$ \\
\hline Rumps, nates and thighs & $33.36^{\mathrm{Bb}}$ & $34.58^{\mathrm{Aa}}$ & $34.06^{\mathrm{AaB}}$ & 34.45 & 33.57 & $1.1867^{3}$ \\
\hline Perirenal fat & 1.95 & 1.97 & 2.26 & $1.77^{\mathrm{B}}$ & $2.35^{A}$ & $0.2648^{3}$ \\
\hline Perivisceral fat & 2.94 & 2.89 & 3.30 & $2.54^{\mathrm{B}}$ & $3.55^{\mathrm{A}}$ & $0.3962^{3}$ \\
\hline Interscapular fat & 0.97 & 0.87 & 0.83 & $0.80^{\mathrm{B}}$ & $0.97^{\mathrm{A}}$ & $0.0522^{3}$ \\
\hline Total fat & 5.86 & 5.73 & 6.39 & $5.11^{\mathrm{B}}$ & $6.87^{A}$ & $1.4725^{3}$ \\
\hline \multicolumn{7}{|l|}{ Hot carcass content $(\mathrm{g})^{2}$} \\
\hline Perirenal fat & 29.8 & 29.2 & 33.6 & $26.9^{\mathrm{B}}$ & $34.8^{\mathrm{A}}$ & $60.40^{4}$ \\
\hline Perivisceral fat & 45.9 & 42.8 & 48.0 & $39.6^{\mathrm{B}}$ & $51.5^{\mathrm{A}}$ & $85.10^{4}$ \\
\hline Interscapular fat & 13.6 & 11.5 & 12.1 & $12.8^{\mathrm{B}}$ & $12.0^{\mathrm{A}}$ & $10.18^{4}$ \\
\hline Total fat & 89.3 & 83.5 & 93.7 & $79.3^{B}$ & $98.2^{\mathrm{A}}$ & $314.18^{4}$ \\
\hline
\end{tabular}

ab Values with different superscripts within the same raw differ by $P<0.05$; $A B$ values with different superscripts within the same row differ by $P<0.01 ;{ }^{1}$ values covariated for initial body weight; ${ }^{2} 124$ degrees of freedom; ${ }^{3} 123$ degrees of freedom; NZW: New Zealand White; H: Hyla; P: Provisal; S: summer; W: winter.

was observed in a recent study undertaken in Germany on male rabbits (Ristic, 1990).

There were similar values for fat deposits among the three genotypes studied. This similarity was true for each type of fat considered: the total fat showed a mean incidence of $6.00 \%$. Given the possible influence of carcass weight on the fat deposits, the absolute values, covariated for hot carcass weight, are also summarized in table $\mathrm{V}$. These data confirm the same trend of the fat deposit percentages.

The data summarizing the effect of the seasons are presented in table $\mathrm{V}$. The $\mathrm{W}$ rabbits had a superior proportion of head and neck (13.52 vs $12.84 \%, P<0.01)$ and shoulders and forelegs (12.25 vs $11.29 \%$, $P<0.01)$ compared with those of $S$ sub- jects. For the thoracic wall $(23.53 \%)$ and loins and flanks $(17.51 \%)$, the values were not significantly different between the rabbits reared under the two environmental conditions. Similar data were also observed for rump, nates and thighs, which had an average value of $34.01 \%$.

There were significant differences in relation to the fatty deposits, which were higher in $W$ rabbits $(P<0.01)$ than in $S$ rabbits. In fact, the winter breeding produced a higher percentage of total fat (6.87 vs $5.11 \%$ ) and perirenal (2.35 vs $1.77 \%$ ), perivisceral (3.55 vs $2.54 \%$ ) and scapular fat (0.97 vs $0.80 \%)$. A similar trend was observed for the fat deposit weight values, covariated for hot carcass weight. The higher adipogenesis of the animals bred in winter was related to 
their higher feed intake caused by the lower temperatures. Rabbits reared during the coldest months ate more. The greater amount of available energy enabled the animals to satisfy their thermoregulation requirements and to achieve a higher adipogenesis. The reduction of the fat deposits under high temperature conditions confirms the results obtained in other experimental studies (Chiericato et al, 1992).

In conclusion, the absence of significant interaction effects between breed and season indicated that the three breed types tested had a similar adaptive capacity to the different environmental conditions.

The purebreds did not differ from hybrid rabbits in terms of growth performance, although there were some differences in their slaughtering and jointing performance. These differences, however, were limited.

The low winter temperatures compared to the high summer levels resulted in poorer feed efficiency and decreased the slaughtering and jointing yields.

\section{ACKNOWLEDGMENTS}

This research was supported by the National Research Council of Italy, Special Project RAISA, subproject no 3 , paper no 2270.

\section{REFERENCES}

AOAC (1984) Official Methods of Analysis. AOAC. William Byrd Press Inc, Richmond, VA, USA

Belgium Government Agricultural Research Centre, Ghent (1984) Comparison of hybrid rabbits. Ann Breed Abstr 52, 4913

Cheeke PR (1987) Rabbit Nutrition and Feeding. Academic Press, Orlando, FL, USA

Chiericato GM, Filotto U (1989) A note on the fattening performance and carcass characteristics of New Zealand White, Hyla and Provisal rabbits. $J$ Appl Rabbit Res 12, 156-158
Chiericato GM, Bailoni L, Rizzi C (1992) The effect of environmental temperature on the performance of growing rabbits. In: Proceedings of the 5 th World Rabbit Congress, Corvallis, OR, USA, 25-30 July 1992, B, 723-731

Grazzani R, Dubini F (1982) Coniglicoltura razionale. Edizione Ottaviano, Milan, Italy

Harvey WR (1989) LSMLMW. PC2 Version. Mixed Model Least Squares and Maximum Likelihood Computer Program. Department of Dairy Science, Ohio State University, Columbus, $\mathrm{OH}, \mathrm{USA}$

INRA (1989) L'alimentation des animaux monogastriques : porc, lapin, volailles. INRA, Paris, France

Lebas F, Ouhayoun J (1987) Incidence du niveau protéique de l'aliment, du milieu d'élevage et de la saison sur la croissance et les qualités bouchères du lapin. Ann Zootech 36, 421-432

Martillotti F, Antongiovanni M, Rizzi L, Santi G, Bittante $G$ (1987) Metodi di analisi degli alimenti di impiego zootecnico. Quaderni Metodologici no 8, IPRA, CNR, Rome, Italy

Maertens L, De Groote G (1990) Comparison of feed intake and milk yield of does under normal and high ambient temperature. J App/ Rabbit Res 13, 159162

Okerman F, Maertens L, De Groote G (1987) Évaluation des performances de reproduction et d'engraissement de quelques souches hybrides de lapins. 2. Comparaison des résultats d'engraissement. Rev Agric 40, 1553-1567

Parigi Bini R, Dalle Rive V (1977) Metodi di stima del valore nutritivo dei mangimi concentrati per conigli in accrescimento. Coniglicoltura 14, 33-40

Ristic M (1990) Effect of sex and final fattening weight on the carcass value of young rabbits. Ann Breed Abstr 58,1159

Ristic M, Zimmermann E (1992) Slaughter value of young rabbits from fattening hybrids and pure breeding animals. J App/ Rabbit Res 15, 827-831

Roca Casanovas T, Costello Llobet JA, Camps Rabada J (1980) Tratado de Cunicultura 2. Real Escuela Oficial y Superior de Avicultura, Barcelona, Spain

Samoggia R (1987) Esigenze fisioclimatiche dei conigli nell'allevamento intensivo. Coniglicoltura 24, 20-24

Simplicio JB, Cervera C, Blas E (1988) Effect of two different diets and temperature on the growth of meat rabbit. In: Proceedings of the 4th World Rabbit Congress, Budapest, Hungary, 10-14 October 1988, III, 74-78

Stephan E (1981) Der Einfluss von Haltungstemperaturen auf die Mastleistung von Fleischkanichen verschiedener Rassen (vorlaufige Mitteilung). KleintierPraxis 26, 313-317 